\title{
THE OPPORTUNITIES AND CHALLENGES ANALYSIS OF THE COFFEE SHOP BUSINESS DURING THE COVID PANDEMIC 19 IN PEKANBARU
}

\author{
Kiki Joesyiana ${ }^{1}$, Asepma Hygi Prihastuti ${ }^{2}$, Desi Susanti ${ }^{3}$ \\ ${ }^{1}$ Economics Science Institute of Persada Bunda, kiki.joesyana@stiepersadabunda.ac.id \\ ${ }^{2}$ Economics Science Institute of Persada Bunda, asepma@stiepersadabunda.ac.id \\ ${ }^{3}$ Economics Science Institute of Persada Bunda, dsusant1.hazel@gmail.com
}

\section{DOI}

https://doi.org/10.26740/jupe.v10n1.p1$\underline{8}$

\author{
Article history \\ Received \\ 1 September 2021 \\ Revised \\ 10 September 2021 \\ Accepted \\ 15 September 2021
}

\section{How to cite \\ Joesyiana, K., Prihastuti, A. H., \& Susanti, D (2022). The Opportunities and Challenges Analysis of the Coffee Shop Business during the Covid Pandemic 19 in Pekanbaru. Jurnal Pendidikan Ekonomi (JUPE), 10(1), 1- 8. \\ https://doi.org/10.26740/jupe.v10n1.p1- $\underline{8}$}

Kata Kunci: Peluang; Tantangan; Bisnis; Coffee Shop; Covid 19; SWOT

Keywords: Opportunities; Challenges; Business; Coffee Shop; Covid 19; SWOT

\section{Corresponding author}

Kiki Joesyiana

kiki.joesyana@stiepersadabunda.ac.id

\begin{abstract}
Abstrak
Saat ini salah satu usaha yang banyak di minati oleh para pelaku bisnis adalah usaha coffee shop, tidak hanya di pekanbaru namun di seluruh indonesia keberadaan usaha coffee shop semakin banyak di temukan. Namun tepat pada awal tahun 2020 dunia di hadapkan dengan pandemi covid 19 yang jelas sangat berdampak pada semua aspek kehidupan termasuk bisnis coffee shop. Tujuan di lakukannya penelitian ini adalah untuk mengetahui peluang dan tantangan yang di hadapi para pelaku bisnis coffee shop dalam menjalankan bisnis nya di masa pandemi covid 19 dan memanfaatkan peluang dan tantangan tersebut agar bisnis coffee shop tetap berjalan dan menghasilkan keuntungan. Metode olahan data dalam penelitian ini menggunakan metode deskriptif kualitatif dan proses analisis dilakukan dengan menggunakan analisis SWOT. Sumber data yang di gunakan yaitu data primer dan sekunder, di mana data di peroleh dari hasil observasi dan wawancara langsung secara mendalam yang berkaitan dengan peluang dan tantangan bisnis coffee shop di masa pandemi covid 19 serta penyebaran angket. Dari hasil analisis SWOT dan matrik SWOT di ketahui bahwa Coffee Shop di Pekanbaru berada pada sel I (Grow and Build). Strategi yang cocok pada posisi sel ini bagi Coffee Shop di Pekanbaru adalah strategi intensif (penetrasi pasar, pengembangan produk dan pengembangan pasar).
\end{abstract}

\section{Abstract}

Currently, the coffee shop is one of the growing trends in the coffee businesses that are of great interest, not only in Pekanbaru but throughout Indonesia, the existence of a coffee shop business is increasing growth. However, in early 2020, the world faced Covid 19 pandemic that is greatly impacting the life aspects including the coffee shop business. This research aims to know the opportunities and challenges as the reference for the owner to run the business ahead in Covid 29 Pandemic and to be more creative to take advantage of its opportunities and challenges to keep the business survived and to make a profit. The Descriptive qualitative analysis was employed in this research with a SWOT framework. Primary and secondary data were used in this research, it was obtained from observation and in-depth interview related to opportunities and challenges of coffee shop business in Covid 19 Pandemic and also the distribution of the questionnaire. SWOT analysis and SWOT matrix show that the Coffee Shop business in Pekanbaru is in cell 1 (Grow and Build). Intensive strategy (market penetration, product development, and market development) was the most appropriate strategy to be implemented in this cell part of the Coffee Shop business in Pekanbaru.
\end{abstract}




\section{BACKGROUND}

The Coffee shop business, a small and medium industry group in Indonesia nowadays is rapid growth and attracted the attention of the government and the business owner. Indonesian Ministry of Industry in kemenperin.go.id says that several considerations have been taken into account to determine the regulation and to do coaching program for the small and medium industry to become efficient and effective in the future, one of them is a coffee shop (Indonesian Ministry of Industry; 2017). Business terminology is originally from English language, that is Business that means bustle. Business means range of activities implemented by individuals or organizations involving the process of making, buying, selling, or exchanging goods or services with the aim of making a profit (Zulaikha. 2020).

Fajrillah et al., (2020) states the business challenges from the external environment is possibly both could be well-predicted and well-handled or vise versa. Therefore, it means that there is no guarantee for the business owner to be in the comfort zone. It could be identified from the current situation, covid 19 Pandemic. Almost all of the business owner, including the coffee shop is greatly impacting by its spread of the virus. With the existence of external challenges, the coffee shop owners have to find strategic ways to face challenges. Currently, Indonesia faced the Covid 19 Pandemic that greatly impacting the constraint and the cessation of business due to the enactment of PSBB to stop the prevention of the covid 19 virus. It is also including Pekanbaru, several businessmen, and business owner were lost and even bankrupt due to the Pandemic. The businessman demanded for adjusting the business based on the current condition. It has to do to ensure the survival of the business and to make a big profit.

Opportunities are a positive trend that is in the external environment of the industry, and if these opportunities are exploited by the business owner, its opportunities have the potential to generate profits for business people in a sustainable manner. Meanwhile, according to Hendro (2011) business opportunities stimulate from an inspiration, idea, or opportunity appears to be used for the benefit of someone both in daily life and in business.

Zimmerer (2009) Says that opportunity is an application of creativity and innovation to solve a certain problem and to seek the opportunities daily. Besides, Robbin and Coulter state that an effort is a process involving the individual or a group of individuals that uses certain ways or facilities to create added value to fill the needs without considering the resources. In further, according to Muchson (2017) business opportunities is an opportunity that can be utilized to be a profitable business.

The following are 6 dimensions of potential business opportunities that can be implemented creatively and innovatively stated by Muchson (2017) : (1) Make Motification, stimulating several changes. (2) Make It Better, strategy to create a better business, (3) Make It The First, it is a strategy to become the first initiator (4) Make It Special Product, create the product specification: (5) Cloning, imitate the product by differentiating the brand and (6) Substitute, become the replacement product.

The development of the business industries, which is currently increasingly competitive, imposed the business owner to become more creative and innovative to run the business ahead. Other economic issues were also greatly impacting the low demand of the consumer. It is a problem that business people constantly face, one of them is a coffee shop businessman. The coffee shop owner nowadays has to take advantage of opportunities to be able to maintain its coffee shop business. Retaining customers is the main focus of the strategies being to be implemented by the 25 coffee shops that are the object of this research.

Coffee shop is a place (shop) that serve espresso and meals (Indonesia Dictionary). The word café is originally from Frech language, that is coffee (Oldenburg, 1989). As time goes by, coffee shop is widely known as a place to consume a coffee drink and others variations of diversified coffee products as well as other meals.

As stated in https://www.tripadvisor.co.id the top 10 coffee shop based on above 4 stars rank and above 300 reviews in Pekanbaru are as follows, Kimteng, Warkop Warkop pinggiran 45, atjeh kupi, peterseli kitchen, dhapu koffie ronggo, leng coffee, Mr. Brewok Cafe \& Resto, Re Caffe Platinum, One Refinery Coffee Shop dan Coffee Toffee Pekanbaru. Current challenges for coffee shop owner is to find the strategic way to maintain the business, to ensure the purchase of the product and the positive response from the customer as well as the revenue. The coffee shop business is greatly impacting by Covid 19 pandemic.

Several businesses that is potentially to establish in Covid 19 Pandemic are as follows: online business, hand sanitizer, mask, frozen foods, herbal concoctions. Coffee shop owners could utilize social media to promote the products in Covid 19 Pandemic. The provisions of Law Number 13, 2003, article 1, paragraph 5 states that business owner is (a) an individual, fellowship, or legal entity who runs a self-owned company; (b) Individuals, associations or legal entities that independently run companies that do not belong to them; (3) Individuals, associations or legal entities located in Indonesia representing companies domiciled outside the territory of Indonesia. It can be 
concluded that in principle, the business owner is the one who runs the business, whether their own-business or not.

To maintain the running of the business in Covid 19 Pandemic, the owner has to be creative to see the opportunities and to handle the challenges. The business owner has to find strategic ways to promote the products. Therefore, the analysis of opportunities and challenges faced by a coffee shop owner in Covid 19 pandemic related to the strategy to maintain the running of the business in Pekanbaru particularly. It is expected that the findings of its analysis could maintain and even increase the numbers of coffee shop consumers as well as expand the business industries, in Pekanbaru particularly.

\section{METHOD}

This research employed qualitative design, qualitative is a research design based on philosophy of pospositiveism, to get the data on natural setting phenomena (Sugiyono. 2017), it discusses SWOT and analysis of each variables, internal factors (strengths and weaknesses) and external factors (opportunity and threat) faced by the coffee shop owner in Pekanbaru.

Population is an area of generalization consisting of objects or subjects that have a specific qualities and characteristics set by researcher to learn from and the conclusion is withdrawn (Sugiyono. 2017). Generally, population refers to a group of objects with the same characteristics that formulate the main problem. The population in this research is coffee shop owner and consumer in Pekanbaru, Riau.

The population in this research is coffee shop consumer in Pekanbaru, Riau. The sample were chosen based on the highest score from Google, has 4 stars identification, and including behavior data, since population is determined by the assessment score anf review given by the user. The assessment rubrics for local in Google platform were as follows:

Table 1 Score Assessment of Google Platform

\begin{tabular}{cc}
\hline 5 stars & Love it \\
\hline 4 stars & Like this \\
\hline 3 stars & Fair \\
\hline 2 stars & Dislike \\
\hline 1 star & Hate \\
\hline
\end{tabular}

The score was calculated from user score and other signals to reflect the business quality in the Google platform. The Seller Rating is the automatic extension that shows the highest rating. It provides users to explore Google to find a qualified business. It will be known if the business has been reviewed more than 300 pupils from the same area of business shop location and also have the calculation of the stars 4 or even more.
Table 2 The Coffee Shop List in Pekanbaru that has stars above 4 and the reviews above 300 reviews

\begin{tabular}{|c|c|c|c|}
\hline No. & Coffee Shop Name & Rating & Total Reviews \\
\hline 1. & Kedai Kopi Kimteng & 4.4 stars & 2.077 \\
\hline 2. & Warkop Pinggiran 45 & 4.1 stars & 1.535 \\
\hline 3. & Atjeh Kupi & 4.4 stars & 1.464 \\
\hline 4. & Peterseli Kitchen & 4.3 stars & 1.314 \\
\hline 5. & Dhapu Koffie Ronggo & 4.4 stars & 1.288 \\
\hline 6. & Leng Coffee & 4.4 stars & 1.022 \\
\hline 7. & Mr. Brewok Cafe \& Resto & 4.3 stars & 1.007 \\
\hline 8. & Re Caffe Platinum & 4.4 stars & 888 \\
\hline 9. & One Refinery Coffee Shop & 4.6 stars & 855 \\
\hline 10. & Coffee Toffee Pekanbaru & 4.2 stars & 846 \\
\hline 11. & Kopi Pao Pekanbaru & 4.3 stars & 782 \\
\hline 12. & Starbuck Coffe Mall SKA & 4.5 stars & 677 \\
\hline 13. & Viz Cafe & 4.2 stars & 667 \\
\hline 14. & KoffiHolic SPBU Jln. Riau & 4.3 stars & 656 \\
\hline 15. & Er Coffee & 4.4 stars & 661 \\
\hline 16. & Raja Coffee & 4.2 stars & 614 \\
\hline 17. & Teras Kopi Sumatra & 4.4 stars & 519 \\
\hline 18. & Krema Coffee 1 & 4.5 stars & 512 \\
\hline 19. & Gerobak Kopi Rambo & 4.3 stars & 508 \\
\hline 20. & RR Cafe & 4.3 stars & 4666 \\
\hline 21. & JJF Coffee Shop & 4.0 stars & 451 \\
\hline 22. & Kedai Kopi Savasana & 4.3 stars & 343 \\
\hline 23. & Erber Coffee Nodal & 4.6 stars & 318 \\
\hline 24. & $\begin{array}{l}\text { Riau Roaster Coffee Lab \& } \\
\text { Pastry }\end{array}$ & 4.7 stars & 312 \\
\hline 25. & $\begin{array}{l}\text { Krema Coffee Soekarno } \\
\text { Hatta }\end{array}$ & 4.5 stars & 309 \\
\hline
\end{tabular}

Source: https://www.tripadvisor.co.id (October, 2020)

\section{RESULT AND DISCUSSION \\ IFE Matrix Analysis}

According to Ariyani (2020) this internal factor is the condition which occurs in a company where it influences the strength and weakness formation and it can influence the company decision. Internal Factor Evaluation (IFE) matrix is the tool of strategic formulation used to summarize and evaluate the main strength and weakness in business functional areas and also to be the foundation to identify and evaluate the correlation between those areas. Intuitive assessment is used in developing internal factor evaluation matrix until its scientific display may not be interpreted as the proof that this technique is truly without any gap. Thorough understanding about the factors covering in it is more important than the existed numbers (Santoso. 2014). 
Table 3 The Analysis Result of IFE Coffee Shop Pekanbaru

\begin{tabular}{|c|c|c|c|c|}
\hline No & $\begin{array}{c}\text { Internal } \\
\text { Factors }\end{array}$ & Points & Rating & Score \\
\hline \multicolumn{5}{|c|}{ Strength } \\
\hline 1 & $\begin{array}{l}\text { The price is } \\
\text { reasonable for } \\
\text { the coffee lover }\end{array}$ & 0,0509 & 3,15 & 0,1606 \\
\hline 2 & $\begin{array}{l}\text { The } \\
\text { interior/exterior } \\
\text { coffee shop } \\
\text { design which } \\
\text { has its own } \\
\text { uniqueness } \\
\text { (concept) }\end{array}$ & 0,0675 & 4,18 & 0,2817 \\
\hline 3 & $\begin{array}{l}\text { There is } \\
\text { entertainment } \\
\text { in the coffee } \\
\text { shop (Live } \\
\text { Music) }\end{array}$ & 0,0656 & 4,06 & 0,2665 \\
\hline 4 & $\begin{array}{l}\text { The Coffee } \\
\text { shop owner } \\
\text { understands } \\
\text { coffee } \\
\text { thoroughly }\end{array}$ & 0,0541 & 3,35 & 0,1814 \\
\hline 5 & $\begin{array}{l}\text { Quick service } \\
\text { at the coffee } \\
\text { shop }\end{array}$ & 0,0487 & 3,02 & 0,1469 \\
\hline 6 & $\begin{array}{l}\text { The availability } \\
\text { of food and } \\
\text { snack product } \\
\text { as the } \\
\text { companion of } \\
\text { coffee drink at } \\
\text { the coffee shop }\end{array}$ & 0,0670 & 4,15 & 0,2776 \\
\hline 7 & $\begin{array}{l}\text { The coffee } \\
\text { taste is suitable } \\
\text { with the coffee } \\
\text { lovers slod at } \\
\text { the coffee shop }\end{array}$ & 0,0705 & 4,37 & 0,3080 \\
\hline 8 & $\begin{array}{l}\text { The coffee } \\
\text { shop situation } \\
\text { is comfortable } \\
\text { to hang out and } \\
\text { gather }\end{array}$ & 0,0692 & 4,28 & 0,2963 \\
\hline 9 & $\begin{array}{l}\text { Using } \\
\text { electronic } \\
\text { payment tool } \\
\text { (Debit/Credit, } \\
\text { Go-Pay, } \\
\text { Shopee Pay, } \\
\text { OVO, t-Cash, } \\
\text { etc) and } \\
\text { gaining Cash } \\
\text { Back }\end{array}$ & 0,0516 & 3,19 & 0,1645 \\
\hline 10 & $\begin{array}{l}\text { Already has } \\
\text { permanent } \\
\text { coffee lover } \\
\text { consumer } \\
\end{array}$ & 0,0614 & 3,80 & 0,2335 \\
\hline
\end{tabular}

\begin{tabular}{|c|c|c|c|c|}
\hline 11 & $\begin{array}{l}\text { The availability } \\
\text { of complete } \\
\text { facilities (Wifi, } \\
\text { toilet, and } \\
\text { musholla } \\
\text { (place for } \\
\text { Islamic prayer) }\end{array}$ & 0,0533 & 3,30 & 0,1757 \\
\hline & $\begin{array}{l}\text { The raw } \\
\text { material quality } \\
\text { (the coffee } \\
\text { seeds) is } \\
\text { guaranteed }\end{array}$ & 0,0634 & 3,92 & 0,2487 \\
\hline
\end{tabular}

\begin{tabular}{|c|c|c|c|c|}
\hline \multicolumn{5}{|c|}{ Weakness } \\
\hline 1 & $\begin{array}{l}\text { Less service } \\
\text { hospitality at } \\
\text { the coffee shop }\end{array}$ & 0,0488 & 3,02 & 0,1476 \\
\hline 2 & $\begin{array}{l}\text { There is taste } \\
\text { variant choice } \\
\text { of coffee sold } \\
\text { at the } \\
\text { competitor } \\
\text { coffee shop }\end{array}$ & 0,0557 & 3,45 & 0,1923 \\
\hline 3 & $\begin{array}{l}\text { There is } \\
\text { availability of } \\
\text { sugar/milk type } \\
\text { for coffee } \\
\text { additional taste } \\
\text { at the } \\
\text { competitor } \\
\text { coffee shop }\end{array}$ & 0,0464 & 2,87 & 0,1331 \\
\hline 4 & $\begin{array}{l}\text { The } \\
\text { modification of } \\
\text { coffee } \\
\text { beverages } \\
\text { offered at the } \\
\text { competitor } \\
\text { coffee shop }\end{array}$ & 0,0682 & 4,22 & 0,2879 \\
\hline 5 & $\begin{array}{l}\text { The competitor } \\
\text { coffee shop } \\
\text { frequently } \\
\text { makes promo }\end{array}$ & 0,0576 & 3,56 & 0,2053 \\
\hline & Total & 1,0000 & & 3,7078 \\
\hline
\end{tabular}

Source: Processed Data, 2020

The analysis of IFE matrix in Table 3 shows that the strengths of industry was "the taste of Coffee was suit with the consumer" with score 0.3080 . On the other hand, the main waknesses is variation of diversified coffee offered by competitor", with score 0.2879 . The total score of IFE matrix is 3.707, it indicates that internal factors of Coffee Shop in Pekanbaru was in strong position in term of utilizing the strengths and solving the weaknesses.

\section{EFE Matrix Analysis}

According to Ariyani (2020), external factor 
influences the formation of opportunity and challenge where this is related to the condition occuring outside the company and influencing the company decision. External Factor Evaluation (EFE) matrix enables the strategic administrators to summarize and evaluate social economic information, culture, demography, environment, politics, government, law, technology, and competition (Santoso. 2013).

Table 4 The Analysis Result of EFE Matrix of Coffee Shop Pekanbaru

\begin{tabular}{|c|c|c|c|c|}
\hline No & External Factors & Points & Rating & Score \\
\hline \multicolumn{5}{|c|}{ Opportunity } \\
\hline 1 & $\begin{array}{l}\text { Promotion in Social } \\
\text { Media (Instagram, } \\
\text { Facebook, Whatsapp, } \\
\text { etc) }\end{array}$ & 0,1324 & 4,5649 & 0,6042 \\
\hline 2 & $\begin{array}{l}\text { Oginal Coffee Variant } \\
\text { offered by competitor is } \\
\text { still categorized into } \\
\text { homogeneous }\end{array}$ & 0,1029 & 3,5496 & 0,3653 \\
\hline 3 & $\begin{array}{l}\text { The usage of coffee } \\
\text { making equipment used } \\
\text { by the competitor is still } \\
\text { minimum because of } \\
\text { the expensive price }\end{array}$ & 0,0936 & 3,2290 & 0,3023 \\
\hline 4 & $\begin{array}{l}\text { Technology } \\
\text { development that } \\
\text { continuously to be } \\
\text { sophisticated to make } \\
\text { coffee and the } \\
\text { companion product }\end{array}$ & 0,1153 & 3,9771 & 0,4586 \\
\hline 5 & $\begin{array}{l}\text { The change of millenial } \\
\text { life style and the coffee } \\
\text { lover }\end{array}$ & 0,1193 & 4,1145 & 0,4909 \\
\hline \multicolumn{5}{|c|}{ Threat } \\
\hline 1 & $\begin{array}{l}\text { The community } \\
\text { economy decreases } \\
\text { because of Covid } 19\end{array}$ & 0,1012 & 3,4885 & 0,3529 \\
\hline 2 & $\begin{array}{l}\text { The price of raw } \\
\text { materials (The Coffee } \\
\text { Seeds) are not stable }\end{array}$ & 0,0914 & 3,1527 & 0,2882 \\
\hline 3 & $\begin{array}{l}\text { There is creative } \\
\text { business (culinary) } \\
\text { substitution/replacement }\end{array}$ & 0,0629 & 2,1679 & 0,1363 \\
\hline 4 & $\begin{array}{l}\text { The Local Government } \\
\text { Regulation for } \\
\text { operational time } \\
\text { limitation when } \\
\text { PSBB/PSBM }\end{array}$ & 0,0987 & 3,4046 & 0,3361 \\
\hline 5 & $\begin{array}{l}\text { There are many new } \\
\text { coffee shops open with } \\
\text { different concepts }\end{array}$ & 0,0823 & 2,8397 & 0,2338 \\
\hline & Total & 1,0000 & & 3,5686 \\
\hline
\end{tabular}

Source: Processed Data, 2020

The analysis of EFE matrix in Table 4 shows that main opportunity of the industries was "Social Media Promotion (Instagram, Facebook, What Apps, dll)" with score 0.6042. Meanwhile, the main threat is the decrease of society economic due to Covid 19 pandemic, the score is 0.3529 , it causes the decreasing of sales transaction in Coffee Shop. The total score of IFE matrix is 3.5686, it indicates that external factor of Coffee Shop in Pekanbaru was in strong position in responding opportunity and avoiding the threats.

\section{IE Matrix Analysis}

Internal-External (IE) Matrix is a simple matrix which form quadrant to map where strategic location is from the company condition (Juliansyah, N. 2020. p. 117). After finding the score of IFE and EFE, the strategic position of the Coffee Shop in Pekanbaru through IE matrix analysis as shown in Figure 1 as follows:

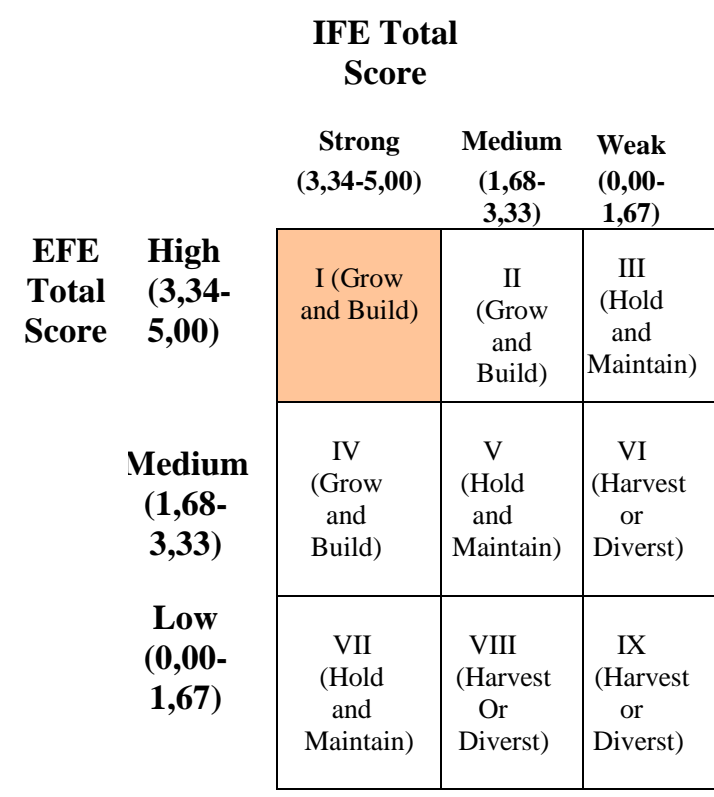

Figure 1 The Analysis of Internal-External (IE) Matrix of Coffee Shop in Pekanbaru

IE matrix have three different strategic implications, it depends on the location of the coffee shop. Based on the result of Table 3 and Table 4, the total score of IFE matrix was 3.7078, and the total score of EFE matrix is 3.5686 . The result of IE matrix shows that Coffee Shop in Pekanbaru is at cell I (Grow and Build). The suitable strategy at this cell for Coffee Shop in Pekanbaru is intensive strategy (market penetration, product development, and market development) or integrative strategy (integration to the back, integration to the front, and horizontal strategy). The alternative strategy which can be done by Coffee Shop in Pekanbaru is intensive strategy. The market penetration that can be done is looking for the larger market for marketing the product or service through more intensive marketing activity such as increasing the number of sales force, increasing the budget for advertisement, intensive sale promotion and increase of product type offer. While for market development, this can 
be done by adding the consumer poulation through social media and application of food and beverage delivery order.

The IE matrix shows that Coffee Shop in Pekanbaru was in Cell 1 (Grow and Build). The most appropriate strategy for this condition is intensive strategic (market penetration, product development, market development) or integrative strategic (backward integration, forward integration, and horizontal integration). The alternative strategic that could be implemented by the Coffee Shop in Pekanbaru is intensive strategy. The possibly market penetration is finding the larger market target to promote the products and services through massive promotion such as the addition of sales force, upgrading budget for advertising.

\section{SWOT Matrix Analysis}

SWOT matrix analysis is a tool used to know the existing strategy implemented by the industries and also to explore other possible and potential strategies for the industries. The following is the result of SWOT matrix analysis from Coffee Shop business in Pekanbaru City:

A. Coffee shop business strength during Covid 19 Pandemic in Pekanbaru City are :

The price is reasonable for the coffee lover

1. The interior/exterior coffee shop design which has its own uniqueness (concept)

2. There is entertainment in the coffee shop (Live Music)

3. The Coffee shop owner understands coffee thoroughly

4. Quick service at the coffee shop

5. The availability of food and snack product as the companion of coffee drink at the coffee shop

6. The coffee taste is suitable with the coffee lovers slod at the coffee shop.

7. The coffee shop situation is comfortable to hang out and gather

8. Using electronic payment tool (Debit/Credit, GoPay, Shopee Pay, OVO, t-Cash, etc) and gaining Cash Back

9. Already has permanent coffee lover consumer

10. The availability of complete facilities (Wifi, toilet, and musholla (place for Islamic prayer).

11. The raw material quality (the coffee seeds) is guaranteed

B. For the weakness of Coffee shop business existed in Pekanbaru City are:

C. Less hospitality service at the coffee shop

D. There is availability of sugar/milk types for additional coffee tasete at the competitor coffee shop.
E. The competitor coffee shop frequently makes promo.

C. For the opportunities which can be utilized from coffee shop business existed in Pekanbaru City during Covid-19 Pandemic are :

1. Promotion in Social Media (Instagram, Facebook, Whatsapp, etc)

2. Original Coffee Variant offered by competitor is still categorized into homogeneous

3. The usage of coffee making equipment used by the competitor is still minimum because of the expensive price.

4. Technology development that continuously to be sophisticated to make coffee and the companion product

5. The change of millenial life style and the coffee lover.

D. For the threats faced by the Coffee shop business owners existed in Pekanbaru City during Covid-19 pandemic are:

1. The community economy decreases because of Covid 19.

2. The price of raw materials (The Coffee Seeds) are not stable

3. There is creative business (culinary) substitution/replacement

4. The Local Government Regulation for operational time limitation when PSBB/PSBM

5. There are many new coffee shops open with different concepts

And from the result of SWOT analysis, coffee shop business during Covid 19 pandemic in Pekanbaru City then it can be concluded that the strategy which can be done by the coffee shop business owners to survive are:

1. Utilizing Social Media owned by the coffee shop in introducing the coffee shop product in details and complete. (strategi memanfaatkan Peluang).

2. Increasing the sale promotion of coffee shop product through social media. (Strategi menghadapi ancaman).

\section{QSP Matrix Analysis}

QSP Matrix is the tool to determine the priority of strategic alternatives that can be implemented by the industries from several recommendation strategies as the result of SWOT matrix analysis. This technique clearly shows the alternative strategy of which one is the best to be selected. QSPM is the tool recommended by strategy experts to conduct alternative strategy selection objectively (Husein Umar. 2008. p. 246). 
It was found 4 strategic alternatives as to the result of SWOT analysis. Then, the attractive score was identified by matching the internal and external strategic factors that can affect the alternative strategy. The multiplication of AS scores with the average score of the main factors to produce Total Attractiveness Score. TAS score is calculated vertically to get the total of attractiveness or Sum Total Attractiveness Scores

Table 5 The Analysis of QSP Matrix at Coffee Shop in Pekanbaru

\begin{tabular}{llc}
\hline No & \multicolumn{1}{c}{ Alternative Strategy } & $\begin{array}{c}\text { Total } \\
\text { Attractiveness } \\
\text { Value (TAS) }\end{array}$ \\
\hline 1 & $\begin{array}{l}\text { Improving the promotion by } \\
\text { utilizing social media such as } \\
\text { Instagram, Facebook, } \\
\text { Whatsapp, Line, etc. }\end{array}$ & 8,190 \\
\hline 2 & $\begin{array}{l}\text { Adding the sales of coffee } \\
\text { beverage product in the form } \\
\text { of bottle/plastic packaging for } \\
\text { online consumers }\end{array}$ & 6,963 \\
\hline 3 & $\begin{array}{l}\text { Doing promotion in the form } \\
\text { of giving discount and special } \\
\text { price on certain days }\end{array}$ & 6,915 \\
\hline 4 & $\begin{array}{l}\text { Adding product type sold such } \\
\text { as coffee powder or coffee } \\
\text { seeds in the packaging }\end{array}$ & 5,853 \\
\hline 5 & $\begin{array}{l}\text { Following the health protocol } \\
\text { which has been determined in } \\
\text { the transaction process and the } \\
\text { product packaging offered }\end{array}$ & \\
\hline Source: Data Processed 2020 & 5,630
\end{tabular}

Source: Data Processed, 2020

The highest score of TAS will be recommended as an interesting priority strategy to be implemented by the coffee shop industries in Pekanbaru. Based on QSP matrix analysis, it can be found that the high priority strategy to be implemented by Coffee Shop in Pekanbaru is increasing the promotion through social media platforms and certain events, as well as promotion in form of discount and special price for certain days.

\section{CONCLUSION}

The findings revealed that the opportunities of the coffee industries in Covid 19 Pandemic are maximizing the online shop promotion through social media such as Instagram, Facebook, WhatsApp, Line, and others. Since the Covid 19 could not be predicted, the coffee owner could produce bottle coffee drinks with a capacity of 250 $\mathrm{ml}-1$ ltr, widely known as "Kopi Literan". With the existence of "kopi literan", the coffee consumer could enjoy the coffee without hanging out due to PSBB regulation. PSBB is regulated due to covid 19 is not a virus to be taken lightly, considering it could cause death, it is reported that since early March, in Indonesia 940.651 were death due to the virus.

Another alternative is the addition of the variation of coffee products such as coffee powder, packaged coffee beans. The consumer could mix their coffee based on their needs. It aims to provide consumers with coffees without direct transaction. Then coffee shop businesses can also collaborate with food / beverages delivery applications such as Go Food and Grab Food so that consumers can more practically shop online with various discount offers every day. By taking advantage of this opportunity, the coffee shop business can stay afloat and get regular income without having to suffer losses, let alone go out of business.

Due to the current Covid 19 pandemic conditions, many coffee shops have experienced a drastic decline in sales, coupled with the imposition of large-scale social restrictions (PSBB) by the central government and local governments. This is a challenge that should be faced by the owners. To stay afloat, in general the coffee shop owner in Pekanbaru has changed their focus from business to business to business to consumer, by attracting consumer interest in the products produced by the coffee shop and starting to make a direct approach to the field by providing and adjusting the product based on what customers need and want. This challenge must be applied by coffee shop entrepreneurs so that their businesses can survive the Covid 19 pandemic.

\section{ACKNOWLEDGEMENT}

Deep gratitude expresses to go to the Ministry of Research and Technology/National Research and Innovation Agency for funding this research as an output of the Beginner Lecturer Research Grant. As well as to the ranks of the leaders and the Chairperson of the LPPM Institute for Economics, Persada Bunda who gave support to the Research Team in completing this research.

\section{REFERENCES}

Ariyani. L, Sion. N, Pusporoni, dll. 2021. Book Chapter Strategi Pemasaran : UMKM dan Pandemi Covid 19. Deepublish.

Fajrillah, Purba. S, dll. 2020. Smart Entrepreneurship : Peluang Bisnis Kreatif \& Inovatif di Era Digital. Yayasan Kita Menulis.

Hendro. 2011. Dasar-dasar Kewirausahaan : Panduan Bagi Mahasiswa Untuk Mengenal, Memahami dan Memasuki Dunia Bisnis. Jakarta. Erlangga

Husein. U. 2008. Strategic Management in Action.. ISSN : 9789796864980. Jakarta. PT Gramedia Pustaka Utama 
Juliansyah, N. 2020. Manajemen Strategi Konsep dan Model Bisnis. Latansa Mashiro Publisher. ISSN 9786239112493.

Muchson, M. 2017. Entrepreneurship (Kewirausahaan). Guepedia.

Oldenburg, Ray. 1989. The Great Good Place: Cafes, Coffee Shop, Bookstores, Bars, Hair Salons, and other Hangouts at The Heart of a Community. London: Da Capo Press.

Santoso, S. 2013. Statistika Ekonomi Plus Aplikasi SPSS. ISBN 979-1068-61-5. Ponorogo: UNMUH Ponorogo Press

Sugiyono. 2017. Metode Penelitian Kuantitatif, Kualitatif, dan R\&D. Bandung: Alfabeta, CV.

Zimmerer, Thomas, W. 2009. Essentials of Entrepreneurship and Small Business Management : Kewirausahaan dan Manajemen Usaha Kecil Buku 1. ISBN 978-979-691-479-1. Jakarta. Salemba Empat

Zulaikha. 2020. Bisnis UMKM di Tengah Pandemi. Unitomo Press. 